\title{
Lume: 20 anos em busca da organicidade
}

\author{
Renato Ferracini
}

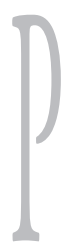

eter Brook diz que o teatro talvez seja uma das artes mais difíceis porque requer três conexôes que devem coexistir em perfeita harmonia: os vínculos do ator com sua vida interior, com seus colegas e com o público (Brook, 2000, p. 26). Concordo plenamente com essa afirmação. A arte de ator como criador de seu próprio trabalho, portanto, realiza-se pela relação quer seja: a relação consigo mesmo, com o outro ator (ou atores) e com o público. E quando o ator consegue, em seu trabalho, atingir a harmonia no amálgama dessas três dimensões, no entrelaçar dessas três linhas, no entrecruzar de todas essas relações, ele se torna um ator orgânico por completo, trocando com o público aquilo que de mais belo existe em sua arte. Nesse sentido, o ator em Estado Cênico é um ser múltiplo por natureza e toda e qualquer reflexão do trabalho de ator, mesmo que se possa definir de maneira clara o recorte de discussão, jamais poderá ignorar completamente as relaçôes multidimensionais e multifacetadas de seu trabalho. Iniciarei por pensar o ator, aqui, não como uma teia de linhas paralelas que são trabalhadas independentes e que, de alguma forma milagrosa, entrelaçam-se quando em Estado Cênico; mas, sim, como uma multiplicidade intimamente relacionada em seus microelementos que são trabalhados em conjunto. Devemos iniciar por tentar verificar que divisões dualistas sobre o trabalho de ator talvez sejam, em um primeiro plano, abstratas e didáticas.

\section{Dimensão mecânica e dimensão orgânica: dimensão única}

Ao realizar um recorte de visão do trabalho de ator em relação a si mesmo, é comum os estudiosos de teatro identificarem outras duas dimensões específicas dentro desse recorte: uma delas seria a faculdade operativa do ator em articular sua arte de maneira concreta, o que comumente chamamos "técnica" e a outra seria a própria faculdade criadora do ator, o momento no qual ele anima a "técnica" insuflando-lhe "vida" e organicidade. Assim sendo, somos tentados a pensar que possa existir um suposto dualismo no trabalho do ator, forma-vida, quando, em realidade, essa divisão dual é apenas didática, conceitual e abstrata, pois o trabalho de ator se constrói pela diagonalização dessas faculdades. Portanto, para que eu possa dar início a um pensamento sobre o trabalho do ator, ao menos do trabalho de ator como eu o vejo,

Renato Ferracini é ator do Lume, pesquisador e doutor em Artes Cênicas pela Unicamp. 
enquanto multiplicidade de linhas e fluxos, devo ter em mente que estes pólos forma-vida não são pontos extremos de uma linha que deve ser dobrada, mas de um "espaço" comum, um "ponto de convergência dimensional" no qual cada dimensão se confunde e se funde com a outra. Não são pólos distantes e contraditórios entre si, mas são centros, pontos, que podem ser trabalhados, na prática cotidiana, de maneira conjunta, mesmo que, no plano conceitual, eles sejam pólos opostos. Na verdade, na dimensão prática de trabalho, não há oposição, mas complementaridade. No corpo, "ponto" por excelência de confluências, não existe polaridade, mas uma multiplicidade dimensional (formal, vital, técnica, relacional etc). Nesse sentido nem mesmo posso definir essa confluência como apenas um ponto, no sentido de um local determinado, mas sim por várias dimensões que ultrapassam, ou passam "entre" a relação de dualidades estabelecidas como forma/expressão.

Dentro de um pensamento dual forma/ vida, é comum a associação do lado formal e preciso do trabalho de ator com a palavra "técnica”. Mas para os gregos, a palavra tékhne significava a fusão conceitual das faculdades formais e artísticas do homem, ou seja, a arte e a técnica não eram pensadas de forma separada, e, portanto, para os gregos essa polaridade era inexistente. A tékhne, para os gregos, era a própria obra de arte. Produto da arte.

Nas reflexões sobre a arte de ator, muitas vezes a palavra e o conceito de "técnica" são utilizados como sinônimo de perfeição, porém uma perfeição fria e mecânica. Aquele ator é frio, muito técnico! - dizem. Ao realizar uma crítica assim, supõe-se que o conceito de técnica esteja somente vinculado ao lado preciso e formal do trabalho do ator. Mas, em realidade, quando criticam um ator dizendo que ele está muito técnico, acredito que queiram dizer que ele, na realidade, está muito mecânico. Um ator mecânico é aquele que não consegue ir além do universo formal de sua arte, enquanto um ator técnico, penso eu, é justamente aquele que vai além dessa mecanicidade, mas tendo como suporte de sua organicidade, essa mesma formalização. Em realidade, o objetivo final do ator é, através de sua técnica, ultrapassar essa mecanicidade, não no sentido de uma ascese a um absoluto idealizado, mas no sentido de uma implosão da dualidade entre as faculdades operativas e criadoras - forma/expressão - que se confluiriam na imanência do próprio corpo do ator, sendo, portanto, a faculdade operativa/ mecânica, um dos elementos necessários desse universo múltiplo que chamamos arte de ator. Em outras palavras, a tékhneltécnica enquanto formalização e agenciamento do próprio corpoem-arte. Assim sendo prefiro cunhar e usar a palavra "técnica" em seu sentido mais amplo de tékhne. Um ator que possui "técnica" passa a ser, dentro desse estudo, um ator que possui a capacidade de operacionalizar sua organicidade, ou seja, atualizar sua "vida" no tempo e no espaço. É um ator que possui a capacidade de harmonia/entrelaçamento entre as capacidades operativas e criadoras da arte de ator. A técnica pensada enquanto implosão da dualidade forma/vida, enquanto tékhne, é justamente a capacidade do ator em ultrapassar esse limite formal. A tékhne, para o ator, é a busca de seu "fluxo de vida intensivo" através dos aspectos formais e precisos da musculatura de seu corpo. Isso não é novo.

A tékhne enquanto conceito que diagonaliza esses universos e territórios do trabalho do ator nos força a repensar o próprio conceito de corpo em estado cênico e buscar desfazer, ou repensar, uma suposta dicotomia que talvez comece a se delinear: corpo em estado cotidiano e corpo em Estado Cênico. Se a tékhne é o conceito que implode este dualismo forma/conteúdo, talvez seja a idéia de um corpo-subjétil que implodirá e transbordará esses conceitos de corpo com comportamento cotidiano e um corpo-em-arte. 


\section{0 corpo-subjétil}

Na prática, um ator que possui técnica, quando em Estado Cênico, busca recriar um comportamento corpóreo que, de certa forma, habite um espaço "entre": nem um corpo somente mecânico e formalizado, nem um corpo somente "vivo", informe e caótico; nem um comportamento cotidiano puro, nem um comportamento extracotidiano puro, mas um corpo ao mesmo tempo formal e orgânico, um corpo que se auto-alimentasse de sua própria potencialidade criando e recriando um comportamento extracotidiano transbordado dele mesmo e nele mesmo e que se lançasse para o espaço gerando, nesse lançamento, uma zona de arte e de inclusão. Isso significa dizer, em última instância, que os comportamentos cotidiano e extracotidiano habitam o mesmo corpo e é o trabalho nesse corpo, para esse corpo e com esse corpo que proporcionará seu comportamento-em-arte, um corpo-em-vida. Posso dizer que essa pesquisa é a base de investigação de todos as linhas de trabalho do Lume. Uma busca de transbordamento das potencialidades e intensividades do corpo, no corpo e para o corpo. Uma pesquisa helicoidal que busca transbordar o corpo nele mesmo. Devemos atentar que, ao pensar o corpo dessa forma, não incorremos no risco de dualismos radicalizantes do tipo: comportamento cotidiano em contraposição com o comportamento em arte, ou ainda, um corpo inserido dentro de uma vida "natural", e cotidiano, e um outro corpo inserido dentro de um Estado Cênico.

A princípio posso dizer que considero o corpo com comportamento cotidiano como um corpo colocado em situações normais do dia-adia; um corpo que, em função de relações históricas, culturais e econômicas, tende à automatização, à acomodação, ao risco de cristalização e engessamento. Mas ao pensar que esse mesmo comportamento nos define, nos identificando como seres históricos inseridos numa cultura específica, não posso simplesmente buscar eliminar esse comportamento coti- diano pensando existir um outro corpo em um suposto estado "puro", pronto para ser encontrado e usado como corpo-em-arte. Isso seria cair em dualismos, além de realizar uma superficialização e mesmo uma certa mistificação sobre a arte de ator. Em realidade, ao pensar em um corpo integrado devo, de certa forma, lançar um outro olhar para esse corpo com comportamento cotidiano e buscar verificar nele uma certa potência artística, um campo de intensividades que pode ser trabalhado e transbordado nele mesmo. Proponho, portanto, não pensar em eliminar esse comportamento cotidiano, mas lutar e trabalhar muito contra a automatização, engessamento e acomodação desse corpo, mas para realizar um mergulho nesses mesmos estratos sociais, históricos, culturais e econômicos que o definem, para, dessa forma, potencializá-lo e transbordá-lo em comportamentos-em-arte. Pensando dessa forma, o corpo-em-arte passa a ser uma espécie de expansão e transbordamento do corpo com comportamento cotidiano, ou seja, o corpo-em-arte é uma espécie de vetor em expansão dele mesmo para ele mesmo como potência artística de sua época e de seu contexto sócio-cultural e econômico. Corpo-hélice-em-arte. Em outras palavras, o corpo em seu comportamento cotidiano, mesmo com sua tendência à lei do mínimo esforço e da acomodação, tem o poder virtual de sua (re)criação e transbordamento dele mesmo para ele mesmo, que pode ser (re)atualizado com muito trabalho e esforço ativo por parte dos atores.

Assim, esse corpo-em-arte não deveria ser conceituado como uma ponta de um dualismo, mas como um corpo integrado e vetorial em relação ao corpo com comportamento cotidiano. Nesse sentido, sugiro chamar esse corpo integrado expandido como corpo-em-arte, esse corpo inserido no Estado Cênico de corpo-subjétil. Explico: ao ler uma obra de Derrida, chamada Enlouquecer o subjétil, essa imagem "corposubjétil" me surgiu de uma maneira extremamente natural. Subjétil seria, segundo Derrida, retomando uma suposta palavra inventada por 
Artaud, aquilo que está no espaço entre o sujeito, o subjetivo e o objeto, o objetivo. Nem um nem outro, mas o espaço "entre". ${ }^{1}$

Outra questão é que essa palavra subjétil pode, por semelhança, ser aproximada da palavra projétil, o que nos leva à imagem de projeção, para fora, um projétil que, lançado para fora, atinge o outro e, como ficará mais claro adiante, também se auto-atinge. Essa aproximação pode ser realizada já que "subjétil" é uma palavra intraduzível, pois, como foi supostamente inventada por Artaud, não existe tradução possível em outras línguas. ${ }^{2}$

É por essas questôes que a imagem de corpo-subjétil surgiu-me de maneira natural para dizer de um corpo em Estado Cênico, um corpo em arte, pois o corpo-subjétil, estando primeiramente nesse "entre" objetividade - subjetividade, dualidade que poderíamos facilmente levar para forma vs. expressão ou mecanicidade vs. "vida", ou mesmo comportamento cotidiano vs. comportamento extracotidiano, não é nem um nem outro exatamente, mas os perpassa pelo meio, englobando as duas pontas da polaridade e todos os outros pontos que passem por essas linhas opostas. Ele não é um ponto ou outro, linha ou outra, mas uma diagonal que atravessa esses pólos abstratos e todos os pontos e linhas "entre". Em segundo lugar porque esse "entre" do subjétil, agindo como um projétil, lança-se para fora para agrupar e incluir o outro, em um movimento que deveria ser natural no trabalho do ator. Portanto, o corpo-subjétil engloba e diagonaliza um espaço "entre" polaridades que se completam e uma ação que lança esse espaço "entre" para fora, numa relação dinâmica. Assim o corpo-subjétil, como a própria palavra subjétil, não é nem objeto, nem sujeito, nem tela, nem projétil, o subjétil pode tornar-se tudo isso, estabilizar-se sob essa ou aquela forma ou moverse sobre qualquer outra forma (1998, p. 45).

O corpo-subjétil proporciona um pensamento transversal sobre a dualidade forma/vida, pois estando nesse "entre" e traçando uma diagonal sobre concepçôes duais, ele gera um outro espaço que, necessariamente, contém todas as oposições, nos obrigando a pensar o trabalho de ator a partir de outro ângulo e dentro de outro território. Além disso, esse pensamento sobre o corpo-subjétil obriga a incluir, também, a ação de projeção que habita o próprio território do conceito de subjétil e, como veremos, habita também, intrinsecamente, o terreno do trabalho do ator. ${ }^{3}$

Sendo o corpo-subjétil composto por uma diagonal técnica/estética, forma/vida, podemos

1 “[...] a palavra ou a coisa [que] pode tomar o lugar do sujeito ou do objeto, não é nem um, nem outro" (Derrida \& Bergstein, 1998, p. 23). "Um subjétil não é um sujeito, muito menos o subjetivo, não é tampouco o objeto, mas exatamente o quê e a questão do "quê" guarda um sentido no que concerne ao que está entre isto ou aquilo [...]” (id., ibid., p. 38).

2 "Pelas duas extremidades de seu corpo, tal palavra, ela também subjétil, suporta, tal qual o desenho de uma quimera, compor com tudo aquilo o que não é ela. Embora pareça tão próximo deles, atrai-os para o artifício de uma semelhança total: o subjetivo e o projétil” (1998, p. 25; grifo dos autores).

3 O corpo-subjétil, habitando um plano de composição - plano da arte - enquanto combinação múltipla-unitária que explode a combinação dualista, ou ainda, a arte de ator enquanto a linha de fuga da máquina dual - seja corpórea/incorpórea, técnica/poética é magnificamente explanado por Deleuze e Guattari: "O plano de composição [plano da arte] pode ser um plano de composição técnica ou estética. Ambos coexistem combinando: No plano de composição técnica, que necessariamente é recoberto ou absorvido pelo plano de composição estética, mas mantendo sua autonomia, a sensação se realiza no material. Nesse caso a figura da arte desfruta de uma aparência de transcendência; no plano de composição estética, não é mais a sensação que se realiza no material, mas é o material que entra na sensação, que certamente não existe mais fora dessa entrada. Nele o plano de composição técnica perde 
olhá-lo não como um ponto, formado por uma estrutura profunda e com um centro localizável, que deve ser esclarecido, entendido, semantizado e rebatido sobre um ou outro plano significante, mas podemos olhar o corpo-subjétil como uma multiplicidade, um espaço de conexôes e re-conexôes infinitas sem qualquer centro ou estrutura, como um continuum de recriação que pode ser quebrado, retomado em outra ponta, reconstruído, mantendo-se numa autoprodução. Enfim, olhar o corpo-subjétil como um rizo$\mathrm{ma}^{4}$ e o corpo-subjétil, pensado como rizoma, nos dá algumas pistas importantes para a reflexão. Uma delas, e que percebemos muito claramente, é que esse rizoma e essa multiplicidade não suportam, nem ao menos, uma dualidade

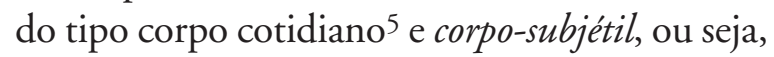
o corpo cotidiano e o corpo-subjétil são um só e mesmo corpo que possuem, no máximo, alguns comportamentos diferenciadores e são esses comportamentos que nos permitem caracterizar, dentro desse corpo múltiplo, um corpo com comportamento cotidiano (corpo cotidiano) e esse mesmo corpo ampliado e vetorizado com um comportamento intensivo (corpo-subjétil). Ao mesmo tempo em que essa verificação de corpo único nos abre muitas frestas, também faz com que olhemos com maior cuidado para alguns pontos; pois, se por um lado, essa independência múltipla do corpo-subjétil nos dá infinitas possibilidades de reflexão independente sobre esse corpo-em-arte, por outro lado ele cria uma suposta grande contradição: ao mesmo tempo em que o corpo-subjétil é borda e limite vetorial de transbordamento do corpo cotidiano e, portanto, depende dele para existir, ele é, em si, independente, pois é o monumento artístico, corpo-em-arte que se sustenta em si e é independente de seu autor. Na verdade essa é uma questão especialmente problemática, e por isso mesmo, devo tentar realizar algumas ponderações sobre essa "divisão interdependente" entre corpo cotidiano e corpo-subjétil.

Não são poucos os textos que cantam a obra como independente de seu autor. Como exemplo, podemos ler em Deleuze e Guattari: "a obra de arte é um ser de sensação e nada mais: ela existe em si” (1992, p. 213). ${ }^{6}$

sua autonomia e as figuras da arte se liberam de uma transcendência aparente confessando seu ateísmo. Contudo só há um plano único, no sentido em que a arte não comporta outro plano diferente do da composição estética: o plano técnico, com efeito, é recoberto ou absorvido pelo plano de composição estética, tornando assim a matéria expressiva" (Deleuze \& Guattari, 1992, p. 248-51, passim).

4 Mas o que vem a ser esse conceito de rizoma? Chamemos Deleuze e Guatarri em auxílio: "[...] qualquer ponto de um rizoma pode ser conectado a qualquer outro e pode sê-lo. É muito diferente da árvore ou da raiz que fixam um ponto, uma ordem. [...] É somente quando o múltiplo é tratado efetivamente como substantivo, multiplicidade, que ele não tem mais nenhuma relação com o uno como sujeito ou como objeto, como realidade natural ou espiritual, como imagem e mundo. As multiplicidades são rizomáticas. [...] Um rizoma pode ser rompido, quebrado em um lugar qualquer e também retomado segundo uma ou outra de suas linhas e segundo outras linhas. [...] Um rizoma não pode ser justificado por nenhum modelo estrutural ou gerativo. Ele é estranho a qualquer idéia de eixo genético ou de estrutura profunda. [...] O rizoma [é] mapa, não decalque. [...] O mapa é aberto, é conectável em todas as suas dimensōes, desmontável, reversível, suscetível de receber modificações constantemente. [...] O rizoma não é feito de unidades, mas de dimensões, ou antes, de direções movediças. Ele não tem começo nem fim, mas sempre um meio pelo qual ele cresce e transborda" (Deleuze \& Guatarri, 1995, p. 15-32).

5 Chamarei, a partir desse momento, esse corpo com comportamento cotidiano discutido acima simplesmente de corpo cotidiano.

6 Ou ainda, numa outra passagem, que a obra de arte, "tornou-se independente de seu modelo, assim como dos outros personagens eventuais: 1) A obra independe do espectador ou do auditor, que se 
Outros se juntam ao coro: os textos de Foucault sobre estética, principalmente em "O que é um autor?" e "Prefácio a Transgressão"7 nos quais ele coloca em xeque tanto a noção de obra como de autor. E Barthes, que com seu texto "A Morte do Autor", também questiona essa relação ao dizer que a obra não pode se reduzir à voz de uma só pessoa, o autor, a entregar a sua confidência (Barthes apud Salem Levy, 2003, p. 58).

Assim como Deleuze, Guattari, Foucault e Barthes, também concordo plenamente, como ator, no ser de sensação independente da poética teatral. E é, justamente, por saber dessa independência, que percebo um suposto paradoxo: ao seguir essa linha de raciocínio e se eu pensar que é do corpo cotidiano que o corposubjétil transborda, talvez eu deva criar uma relação de completa independência entre o corposubjétil e o corpo cotidiano, já que é necessário separar e deslocar o autor (corpo cotidiano) e o suporte da obra que sustenta o ser de sensação (corpo-subjétil), pois a obra existe em si e é independente em relação ao seu criador. Mas esse pensamento é, a priori, infundado, pois o corpo-subjétil e o corpo cotidiano não são independentes; na verdade eles são um só. O corpo em Estado Cênico, recriando açōes físicas em relação dinâmica, é o próprio suporte do ser de sensação que se conserva, cujo comportamentoem-arte é recriado a cada instante na superfície do corpo cotidiano. Temos, no caso do corposubjétil, como já verificado, uma fusão entre o suporte do ser de sensação e o criador no momento da própria criação. Claro que essa fusão existe também em pintura, literatura, escultura e em todas as outras formas de expressão artística no momento da criação. O suporte que com- portará o ser de sensação vai sendo construído nessa fusão para depois se tornar independente. $\mathrm{O}$ pintor se funde com a obra ao pintá-la; mas, ao finalizá-la, a obra passa a existir em si mes$\mathrm{ma}$, independente do pintor. $\mathrm{O}$ quadro passa a ser um suporte material finito do ser de sensação que nasce no momento da última pincelada. E não precisaremos, de forma alguma, conhecer o pintor, nem suas frustraçōes ou alegrias, nem suas obras anteriores ou posteriores, para fruirmos esse quadro e sermos afetados por ele. Mas no caso do trabalho de ator esse "depois", ou essa "última pincelada" não existem, pois o ser de sensação vai sendo criado nessa fusão corpo cotidiano/corpo-subjétil no momento da própria fruição da obra. Seu suporte se desvanece e somente existe no momento do Estado Cênico, no momento em que o ator (enquanto obra e criador), o espaço e o espectador estão, conjuntamente, gerando uma espécie de zona de arte. E talvez aqui esteja o ponto: a independência do ser de sensação talvez esteja nessa zona de arte. Se assim for, podemos dizer que o ser de sensação de um corpo-subjétil não está localizado em um ponto ou um suporte material específico, mas se localiza em um espaço virtual, porém real, dentro ou através da própria ação de vetorização e transbordamento do corpo cotidiano em corpo-subjétil. O ser de sensação que tem o corposubjétil como suporte existe, portanto, na vetorização dinâmica e transbordamento que se estabelece com o corpo cotidiano e com todas as outras relações estabelecidas em um Estado Cênico. Dessa forma, no caso do teatro, o ser de sensação encontra seu suporte em uma ação relacional, não em um material durável. Como veremos mais adiante, a geração de um corposubjétil não é determinada por um ou outro ele-

limitam a experimentá-la. 2) A obra independe do criador, pela auto posição do criado, que se conserva em si. [...] A obra de arte é um bloco de sensações, isto é, um composto de perceptos e afectos. É exatamente este bloco que se conserva" (1992, p. 213).

7 Esses textos podem ser encontrados no livro Ditos e Escritos III (2003) que contém uma coletânea de textos de Foucault sobre estética. 
mento, ou mesmo pelo conjunto deles, mas é determinada pelas relaçóes entre os elementos, ou conjunto deles, que se autoproduzem. Dessa forma, a pergunta sobre quem gera essa ação, essa autoprodução, na tentativa de busca de um suposto autor desse ser de sensação, é infundada. Não existe autor. O corpo-subjétil se autoproduz por entre a relação e inter-relação de vários elementos que se amalgamam no Estado Cênico e, dessa forma, o autor - no caso, aqui, o "eu" ator - dilui-se nessas mesmas relações. Aliás, para ser mais preciso, para que o ser de sensação possa existir, o ator busca diluir-se, tornar-se invisível, abrir mão de sua identidade, de seu "eu" enquanto sujeito. Assim, o ser de sensação do corpo-subjétil estando localizado em uma ação - e não em um material, seja subjetivo (pessoa, identidade, sujeito, personagem) ou objetivo (corpo muscular) - passa a ser independente do autor. Pensando dessa forma, não vejo qualquer problema em verificar uma característica intrínseca do corpo-subjétil: dependência e independência coexistentes nele mesmo. $\mathrm{O}$ ser de sensação, tendo como suporte as relações dinâmicas que estabelecem o corpo-subjétil em Estado Cênico, é independente, mas o corpo-subjétil depende do corpo cotidiano para se suportar em si mesmo, pois, além dele ser gerado nessa vetorização e transbordamento, o corpo cotidiano é o território primeiro do corpo-subjétil.

Podemos pensar, mais precisamente, que o corpo-subjétil, como um corpo nômade, é uma reterritorialização de um corpo cotidiano dester- ritorializado, sendo que esse movimento desterritorialização-reterritorialização não acontece de maneira pontual e única, mas acontece em devir ${ }^{8}$, ou seja, em processo dinâmico macro e/ ou microscópico, em movimento, em retorno constante, em ziguezague, em transformação. Ele é um eterno presente que se constrói e se desvanece ao mesmo tempo. Um ziguezague de territorialização-desterritorialização entre corpo cotidiano e seu próprio transbordamento enquanto corpo-subjétil. O passado também não existe nesse estado, apesar de depender dele como base de recriação. $\mathrm{O}$ passado, enquanto memória ou reminiscência do corpo, ou ainda, a técnica corporal, enquanto possibilidade de articulação da organicidade no tempo-espaço, é um suporte, ou "porta de entrada" para o corposubjétil que torna possível a recriação da ação física a ser recriada naquele presente. Recriar a ação física e não simplesmente repeti-la ou retomá-la enquanto macro e micro-densidades musculares. O corpo-subjétil, enquanto fluxo de açōes físicas, realiza-se, portanto, por ser um presente que se cria a cada instante. Antes de ser um corpo definido a priori, é, na verdade, um corpo que vai sendo definido a cada momento e também se desvanece a cada instante. Ele nunca poderá ser definido ou localizado de maneira exata, a não ser no momento ínfimo de seu suporte que é, em si, indiscernível, mas, de certa forma, percebido. É um acontecimento, um continuum que se desvanece e entra na sensação. Entre corpo cotidiano e corpo-subjétil

8 "Um devir não é uma correspondência de relações. Mas tampouco é uma semelhança, uma imitação e, em última instância, uma identificação. [...] Devir não é progredir nem regredir segundo uma série, e sobretudo devir não se faz na imaginação, mesmo quando a imaginação atinge o nível cósmico ou dinâmico mais elevado como em Jung ou Bachelard. [...] O devir não produz outra coisa senão ele próprio. É uma falsa alternativa que nos faz dizer: ou imitamos ou somos. O que é real é o próprio devir, o bloco de devir, e não os termos supostamente fixos pelos quais passaria aquele que se torna" (Deleuze \& Guattari, 1997, p. 18). "No devir não há passado, nem futuro, e sequer presente; não há história. Trata-se, antes, no devir de involuir: não é nem regredir, nem progredir. Devir é tornar-se cada vez mais sóbrio, cada vez mais simples, tornar-se cada vez mais deserto e, assim, mais povoado. É isso que é difícil de explicar: a que ponto involuir é, evidentemente, o contrário de evoluir, mas, também, o contrário de regredir, retornar a infância ou a um mundo primitivo" (Deleuze $\&$ Parnet, 1998, p. 39). 
não há linha, fronteira ou borda apesar de o corpo-subjétil ser um limiar, ser em si mesmo, borda. É esse instante - sem passado, sem futuro, sem borda, desvanecível e virtual - apenas esse momento ínfimo, que é independente, mas mesmo assim propicia ao ser de sensação sua duração e sua conservação, pois tem a duração da recriação em continuum, gerando, nesse fluxo, pontos fugazes de eternidade coexistentes com sua efemeridade. Deleuze e Guattari, mesmo sem citar diretamente o trabalho de ator enquanto (re)criador do corpo, nos dão essa abertura: "Mesmo se o material só durasse alguns segundos, daria a sensação o poder de existir e de se conservar em si, na eternidade que coexiste com essa duração" (Deleuze e Guattari, 1992, p. 216; grifo dos autores). O corpo-subjétil se realiza pelo devir e pelo múltiplo, que é sua característica intrínseca. Qualquer teoria que busque pensar esse corpo-em-arte deve ter em mente esse universo extremamente complexo e deve residir nesse mesmo território de devir, fluxo e multiplicidade inerente.

Mas o que faz com que esse movimento em continuum entre corpo cotidiano e corposubjétil aconteça? Deve haver alguma força ou elemento que, de alguma forma, seja responsável pela própria vetorização e transbordamento na construção de um corpo-subjétil. E a maior dificuldade se encontra, justamente, nesse ponto, quando busco analisar o fluxo de "vida" que "anima” essa vetorização e transbordamento no tempo/espaço que expande mecanicidade em tékhne ou potencializa e atualiza o corpo cotidiano em corpo-subjétil. O que causa esse salto? Claro que não é apenas uma força ou um elemento, mas um conjunto deles. Acredito que um dos principais ingredientes para essa transformação é aquilo que atores, diretores e teóricos do teatro, muitas vezes, chamam de "organicidade". Talvez ela seja uma força fundamental; pois, como veremos, é a responsável, em meu modo de ver, por manter outros elementos coesos e em constante relação dinâmica. Falemos um pouco sobre organicidade.

\section{Organicidade: 0 elemento que dinamiza o corpo-subjétil}

Essa geradora de "vida" do trabalho de ator que muitas vezes é traduzida por "organicidade" ou ainda "vida" - está em um grande "buraco" conceitual, de dificílima compreensão. Portanto, a grande questão é: o que é essa "vida", o que a conceitua? Acredito que o trabalho de ator está calcado nessa pequena palavra, mas não em sua semântica estagnada, vida/signo nomeada, simplificada. Estou tentando dizer daquela "vida" que a todo tempo se transforma, fluxo constante, naquela sensação muscular como agitação de algo quase indizível, intensivo. Circularidade. Velocidade. Em movimento. Sem parar, sem estagnar. "Vida" no corpo-subjétil enquanto capacidade de uma certa espontaneidade enquanto autoprodução. Um corpo-subjétil que possui uma capacidade de se manter em pé, autoproduzindo uma "vida inorgânica", "vida artificial” transbordada do próprio organismo do corpo cotidiano. Essa vida-inorgânica transbordada do corpo cotidiano é o que alguns estudiosos da área teatral chamam, justamente, de organicidade. Mas, afinal, o que vem a ser organicidade? Existe alguma definição específica para ela? Vejamos algumas: Para Stanislavski "organicidade" significava as
leis naturais da vida "cotidiana" a qual, atra-
vés de uma estruturação e composição, apare-
cia em cena e se transformava em arte; en-
quanto que para Grotowski, organicidade in-
dica algo como a potencialidade de uma cor-
rente de impulsos, uma corrente quase-bioló-
gica que vem de "dentro" e sai acompanhada
de uma ação precisa (Richards, 1995, p. 93). ${ }^{9}$

9 For Stanislavski, "organicity" signified the natural laws of "normal" life which, by means of structure and composition, appear on the stage and become art; while for Grotowski, organicity indicates something like 
Enquanto que para Stanislavski a organicidade está localizada na vida normal e cotidiana e o ator, através de um estudo aprofundado desse mesmo cotidiano, estruturando-o e recompondo-o através de ações físicas, pode, de certa forma, recriar essa mesma organicidade na cena, para Grotowski a organicidade se localiza no próprio corpo do ator, em seus impulsos mais "interiores" e "profundos", em um nível não-cotidiano, mas em um nível que ele chama de "primário", além dos vícios de comportamento e dos clichês da vida cotidiana.

O que é organicidade? É a vida em acordo com as leis naturais, mas em um nível primário. [...] Organicidade está conectada a um aspecto-criança. A criança é, quase sempre, orgânica. Organicidade é algo que se tem mais quando jovens, menos quando ficamos mais velhos. Obviamente é possível prolongar a organicidade lutando contra os hábitos, contra as imposiçôes da vida cotidiana, quebrando, eliminando os clichês do comportamento (Grotowski apud Richards, 1995, p. 66)..$^{10}$

Mas esse conceito de "organicidade", mesmo dentro das colocações de Richards lendo Stanislavski, e de Grotowski, pode gerar um interessante paradoxo, visto que relaciona diretamente o "orgânico", ou "organicidade", enquanto conectados a um organismo - organicidade enquanto uma forma, um fluxo de organização "natural" dos órgãos naturais, conceito que habita o território da construção biológica, natural, relacionada à natureza e ao corpo cotidiano ou à vida cotidiana - com o plano artístico, para o qual, geralmente, utilizamos a pala- vra "inorgânico", ou "artificial" para falar sobre uma obra de arte, pois é uma criação não-natural, não proveniente da natureza, construção humana, antropomórfica. Mas será que a organicidade de um sistema natural, como a do corpo humano, é a mesma organicidade que gera a "vida" necessária a um sistema "artificial" como o corpo-subjétil? Na verdade, acredito que a organicidade que gera "vida" em um sistema complexo como o corpo-subjétil é muito diferente da organicidade que rege um sistema "natural" como o corpo humano, apesar de verificar uma complexidade intrínseca a ambas e de saber que o corpo-subjétil é vetorização e transbordamento do corpo-cotidiano. Portanto, deve ficar claro que quando utilizo a palavra "organicidade" ou "orgânico", não pretendo lançar o leitor nem somente para o conceito de "orgânico" enquanto natureza e nem para um suposto paradoxo do tipo: o corpo do ator (natureza) gerando uma arte inorgânica (não natureza) através do próprio corpo do ator (natureza) - paradoxo, esse, intrínseco ao trabalho do ator, como vimos acima. Em realidade, o conceito de "organicidade" que discuto aqui não está diretamente vinculado nem à visão de Stanislavski nem à de Grotowski, ou seja, não se localiza nem em um elemento de comportamento coletivo, como na vida cotidiana, e nem somente em uma dimensão supostamente "primária" no "interior" de um corpo que, de certa forma, acaba fundindo a organicidade do sistema corpóreo da natureza - corpo cotidiano - com a organicidade da arte de ator. Apesar de acreditar, como Grotowski, que a organicidade esteja, de certa forma, vinculada a uma espécie de desautomatização do corpo cotidiano e, também, de acreditar, como

the potentiality of a current of impulses, a quasi-biological current that comes from the "inside" and goes toward the accomplishment of a precise action.

10 What is organicity? It is to live in agreement with natural laws, but on a primary level. [...] Organicity is linked to a child-aspect. The child is almost always organic. Organicity is something which one has more of when one is young, less of as one gets older. Obviously, it is possible to prolong the life of organicity by fighting against habits, against the training of commom life, eliminating the clichés of behavior. 
Stanislavski, que ela necessita de grande estruturação e composição por parte do ator, ou seja, necessita de muito trabalho para poder ser operacionalizada.

A organicidade, como a vejo em meu trabalho, é uma espécie de força que gera o próprio corpo-subjétil e, portanto, gera o próprio estado de arte dentro do Estado Cênico. E, enquanto estado de arte, o corpo-subjétil atravessa a suposta dualidade - artificial no sentido artístico e orgânico no sentido da natureza - criando um orgânico/inorgânico coexistente, corpotempo-espaço-outro, que se auto-sustenta em si mesmo. Em outras palavras, a organicidade gera um estado orgânico/inorgânico, natural/artificial coexistentes em um mesmo sistema. E como o Estado Cênico é composto por um sistema que relaciona dinamicamente vários elementos, a organicidade, como a vejo, é justamente a força que aproxima e mantém unidos esses vários elementos. Sendo definida como força, não pode ser um elemento concreto que possa ser pontuado ou quantificado. A organicidade, aglutinando os vários elementos que compõem o corpo-subjétil em relação dinâmica (pois a organicidade é intrínseca ao corpo-subjétil) acaba pressionando-o a suspender e arrancar do próprio tempo e do próprio espaço um tempo-espaço outro: um tempo não-cronológico, mas um acontecimento; um espaço nãolinear, mas multidimensional. Um tempo-acontecimento que, por mais fugaz e efêmero que seja, dura, perdura e ecoa porque afeta e é afetado. Esse tempo-acontecimento se autogera nos elementos que habitam o território "entre" orgânico e inorgânico, que é, portanto, comum aos dois. Talvez devamos dizer do ator orgânico em Estado Cênico - do corpo-subjétil que possui organicidade - o mesmo que Otávio Paz diz do poeta: $O$ tempo do poeta: viver em dia, e vivêlo simultaneamente, de duas maneiras contraditórias: como se fosse interminável e como se fosse acabar agora mesmo (Paz, 2003, p. 106). Um ator, quando em Estado Cênico pleno de organicidade - corpo-subjétil - produz uma zona que engloba ele mesmo - ator em todo seu caráter múltiplo que diagonaliza sua dimensão orgânica (natureza) e inorgânica (artificial) - e também o próprio público em múltiplos devires sensíveis, lançando todos em um estado-de-arte no tempo-acontecimento do Estado Cênico.

A "vida", ou simplesmente, a organicidade no trabalho de ator, enquanto força responsável pela relação dinâmica de tantos e tantos elementos, não pode, portanto, ser um ponto definível que possa ser localizado, nem dentro de uma suposta in-corporeidade virtual, nem dentro de um organismo corporal material, nem dentro de qualquer elemento individual. A organicidade no trabalho de ator se realiza por uma diagonal que atravessa essas duas "vidas" (corpórea e incorpórea), funde-se com elas formando uma grande outra "vida" no corpo-subjétil, gerando uma força que mantém coesos todos os seus elementos constituintes. Organicidade como glúon. O glúon é uma das quatro forças elementares da natureza e é a responsável por manter as partículas de quarks presas dentro dos prótons e nêutrons. O termo glúon deriva de glue, cola em inglês. Assim como o glúon é a força forte responsável por manter partículas elementares, como os quarks, coesas e "coladas" formando os prótons e nêutrons que formarão os átomos e, por conseguinte, toda a matéria orgânica e inorgânica do universo, também a organicidade, no trabalho do ator, pode ser considerada uma força glúon, virtual, mas real e concreta, que mantém todos os elementos e subelementos que operam o trabalho de ator coesos e em constante relação dinâmica.

Mas essa correspondência não é de todo correta, pois existe uma característica da organicidade que a difere substancialmente de sua correlação com o glúon. Enquanto o glúon é uma força elementar da natureza que existe em si, a organicidade é uma espécie de glúon especial que somente existe se, ao menos, alguns elementos que ela coloca em dinâmica estiverem presentes. Em outras palavras: a organicidade é uma força que não existe em si mesma; sua existência depende, pelo menos, da relação dos elementos que constituem o corpo-subjétil. É jus- 
tamente aqui que me distancio das definiçóes de organicidade tais quais colocam Grotowski, Stanislavski e Richards, pois ela não preexiste, não é um "algo" que deve ser encontrado ou reencontrado em algum "interior" do corpo cotidiano, mas ela deve ser trabalhada, gerada e pressionada concretamente por entre todos os elementos constituintes do corpo-subjétil. A organicidade coloca o corpo-subjétil em relação dinâmica com seus elementos constituintes e, ao mesmo tempo, são esses mesmos elementos constituintes em relação que geram a organicidade. E quais seriam esses elementos? Podemos citar alguns deles que, de certa forma, nos revelam a complexidade de se pensar organicidade: a manipulação de sua energia e da "presença atoral” no tempo e no espaço; a tékhne e seus princípios pré-expressivos; a possibilidade concreta de recriação de suas ações a cada apresentação; elementos que operacionalizam a criação de uma zona de inclusão, vizinhança e "troca" com o público. Enfim, a organicidade sendo criada e ao mesmo tempo operando como glúon de todos esses elementos - em si mesmos múltiplos - no próprio corpo-subjétil, diagonalizando seu universo corpóreo (dizível, palpável, exterior, atual) e incorpóreo (indizível, sensível, intensivo, virtual).

Dizer que um "corpo atoral” é orgânico é o mesmo que dizer que existe um corpo-subjétil ou ainda que um ator é "vivo". A organicidade é a capacidade relacional em dinâmica de todos os elementos, virtuais e atuais que constituem esse corpo-subjétil. É o elemento que coloca a máquina poética de jogo em movimento. Portanto, não pode ser pensada de modo pontual e definida, e daí vem sua dificuldade de conceituação. A organicidade não se realiza por qualquer um dos elementos, mas a ausência de qualquer elemento faz com que a organicidade não exista. Nesse sentido é que organicidade é "vida" do ator, "vida" do corpo-subjétil. Um elemento vivo se realiza, em termos biológicos, por ser uma máquina autopoiética, ${ }^{11}$ de autogestão circular de seus elementos. O mesmo é a vida do ator, enquanto máquina poética, corpo-subjétil, vida "entre" corpórea/incorpórea, orgânical inorgânica do ator. A organicidade é a aderência dos elementos, o glúon, uma força que os recria a cada instante. A organicidade é uma força que faz circular essas multiplicidades. Ela não se pontua, mora nas reticências...

Buscar ensinar um ator a ser orgânico seria o mesmo que ensinar a gerar vida em algo inanimado. Seria ensinar a potência de criação. Isso não se ensina, mas vimos que cada corpo cotidiano possui essa potência, essa capacidade de criação. E então podemos, enquanto atores, forçá-la, trabalhá-la, instigá-la, expandi-la; buscar descobrir, dentro de um plano singular, como movimentá-la, como lançá-la em motocontínuo. E para isso devemos criar um espaço de desejo, criar um querer, não um querer simples da vontade, mas um querer além vontade,

11 "Naquele momento, também percebi que não é o fluxo de matéria ou fluxo de energia como fluxo de matéria ou energia, nem nenhum componente particular como componentes com propriedades especiais o que de fato faz e define o ser vivo como tal. Um ser vivo ocorre e consiste na dinâmica de realização de uma rede de transformações e de produções moleculares, de maneira tal que todas as moléculas produzidas e transformadas no operar dessa rede fazem parte da rede [...] percebi que o ser vivo não é um conjunto de moléculas, mas uma dinâmica molecular, um processo que acontece como unidade separada e singular como resultado do operar e no operar. Das diferentes classes de moléculas que a compõem, em um interjogo de interações e relações de proximidade que o especificam como uma rede fechada de câmbios e sínteses moleculares que produzem as mesmas classes de moléculas que a constituem, configurando uma dinâmica que ao mesmo tempo especifica em cada instante seus limites e extensão" (Maturana \& Varela, 1997, p. 15). 
um querer/desejo, ao mesmo tempo, telúrico e divino que possa acenar para novas possibilidades de existência.

Função da arte: gerar potência de vida. Deveria ser esse o desejo do ator em relação ao público: através de seu trabalho, convidar o es- pectador, não somente para fruir o espetáculo, mas a criar com ele faíscas de vida e de respiro dentro dos próprios estratos e agenciamentos comuns à vida cotidiana, pois a organicidade é vida orgânica/inorgânica, potência de linha de fuga-em-arte.

\section{Referências bibliográficas}

BROOK, Peter. A porta aberta: reflexões sobre a interpretação e o teatro. Tradução de Antonio Mercado. Rio de Janeiro: Civilização Brasileira, 2000.

DELEUZE, Gilles \& GUATTARI, Felix. O que é filosofia. Trad. de Bento Prado Jr. e Alberto Alonso Muñoz. Rio de Janeiro: Editora 34, 1992.

. Mil Platôs: capitalismo e esquizofrenia. Vol. 1. Trad. de Aurélio Guerra Neto e Célia Pinto Costa. Rio de Janeiro: Editora 34, 1995.

. Mil Platôs: capitalismo e esquizofrenia. Vol. 4. Trad. de Suely Rolnik. Rio de Janeiro: Editora 34, 1997.

DELEUZE, Gilles \& PARNET, Claire. Diálogos. Trad. de Eloísa Araújo Ribeiro. São Paulo: Editora Escuta, 1998.

DERRIDA, Jacques \& BERGSTEIN, Lena. Enlouquecer o subjéctil. Trad. de Geraldo Gerson de Souza. São Paulo: Fundação Editora da UNESP, 1998.

FOUCAULT, Michel. Estética: literatura e pintura, música e cinema. Coleção Ditos e Escritos III. Organização de Manoel Barros da Motta. Trad. de Vera Lucia Avellar Robeiro. Rio de Janeiro: Forense Universitária, 2003.

LEVY, Tatiana Salem. A experiência do fora - Blanchot, Foucault e Deleuze. Rio de Janeiro: Relume Dumará, 2003

MATURANA, Humberto \& VARELA, Francisco. De máquinas e seres vivos - Autopoiese - A organização do vivo. Trad. de Juan Açuña Llorens. Porto Alegre: Artes Médicas, 1997.

PAZ, Otavio. Signos em rotação. Trad. de Sebastião Uchôa Leite. São Paulo: Perspectiva, 2003.

RICHARDS, Thomas. At work with Grotowski on phisical actions. London: Routledge, 1995. 